\title{
Huguianas
}

\section{Aulas pandêmicas}

\section{Hugo Rodas}

Universidade de Brasília

Professor Emérito 


\section{Resumo}

Reflexões sobre o fazer arte em tempo de pandemia.

Palavras-chave: Arte, Sobrevivência, Criatividade, Pandemia.

\section{Abstract}

Some thoughts on making art in pandemic times.

Keywords: Art, Survival, Creativity, Pandemic. 


\footnotetext{
into que todos estamos como caminhando num labirinto, encontrando soluções para suportar a prova, até chegar ao fim dele - se é que esse fim existe. Sinto que depois de 180 dias onde quase cada um deles perdeu seu nome, onde as horas se confundem e a noite passou a ser dia, onde a alegria do encontro depende de este miserável aparato que tenho na minha frente, e que por sorte existe senão seria pior, onde temos tido que encontrar soluções para trabalhar, amar e não desaparecer, onde a mediocridade aflora por todos lados e você tem que lutar para não cair em ela, onde todos parecemos brilhar nessa nova constelação internética, tudo me tem parecido possivel, menos dar aula, a falta de espaço, de equipamento adequado e, sobretudo, a falta de um trabalho comum, de uma respiração comum, do toque, do olhar, do se sentir presente no outro me tem revoltado, angustiado um pouco, coisa não muito comum em mim, mas para quem tem a certeza de que o trabalho de grupo é o que tem mantido o teatro no seu lugar é muito difícil, mas aqui estamos eu e os que sobreviverão na turma do TEAC, (técnicas, experimentais nas artes cênicas) mais experimentais que nunca.

Não deixa de ser um desafio, coisa que de alguma maneira alimenta o continuar andando.
} 